\title{
Preterm Infant
}

National Cancer Institute

\section{Source}

National Cancer Institute. Preterm Infant. NCI Thesaurus. Code C49642.

A newborn infant less than 37 weeks, 0 days gestational age. 